\title{
Adrenergic Antagonist
}

National Cancer Institute

\section{Source}

National Cancer Institute. Adrenergic Antagonist. NCI Thesaurus. Code C72900.

Any agent that binds to and inhibits adrenergic receptors. 